\title{
Understanding the drivers of financial inclusion in South Africa
}

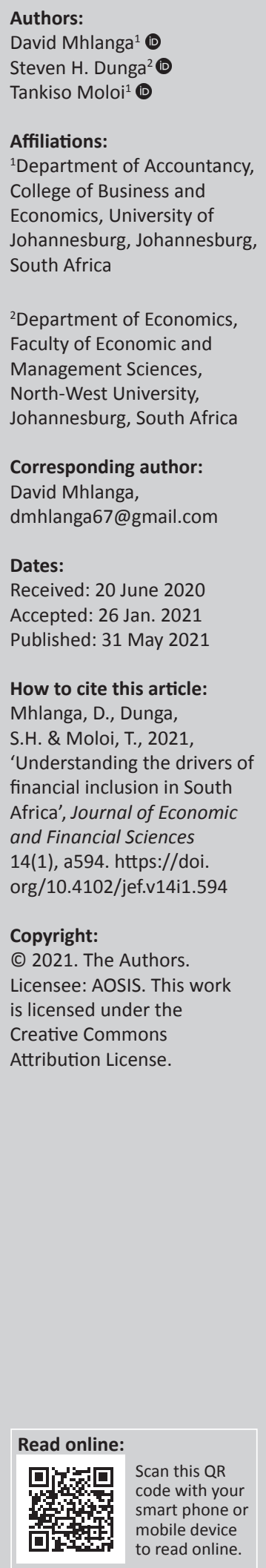

Orientation: Financial inclusion is becoming one of the attractive topics at the global level with policymakers, development partners, governments and financial institutions developing interest in understanding it more deeply.

Research purpose: The study sought to establish the drivers of financial inclusion in South Africa with a focus on factors that influences ownership of an investment account.

Motivation for the study: Motivated by the increase in the evidence of the importance of financial inclusion in fighting poverty and the fact that by merely having a bank account, financial inclusion cannot be guaranteed, the study interrogated the factors that influence households to have an investment account.

Research approach/design and method: As the dependent variable of financial inclusion was binary, the logistic regression was used to estimate the drivers of financial inclusion. The variable assumed two values 0 and 1, where 1 represents access to an investment account and 0 otherwise.

Main findings: Using the logit model, the study discovered that financial inclusion is driven by age, education level, the total salary proxy of income, race, and marital status.

Practical/managerial implications: The differences in the probability of demand for financial products and services amongst the different races mean that products and services tailormade to satisfy the needs of the different races, for coloured and black people these products and services should be designed to improve financial inclusion amongst them.

Contribution/value-add: The study managed to discover the factors that influences households to have an investment account in South Africa.

Keywords: financial inclusion; logit model; drivers; South Africa; investment account.

\section{Introduction and background}

Financial inclusion is increasingly becoming one of the attractive topics at the global level with policymakers, development partners, governments and financial institutions developing interest in understanding it more deeply (Sarma \& Pais 2008; Wentzel et al. 2016). The World Bank Group (WBG) in 2017, clearly highlighted that governments in different countries are developing National Financial Inclusion Strategies (NFIS) to ensure that financial inclusion commitments are achieved. National Financial Inclusion Strategies can be defined as roadmaps of actions, agreed and defined at the national or subnational level (WBG 2017, 2018; Wentzel et al. 2016). This alone discloses how critical is the doctrine of financial inclusion. The National Payment System Framework and Strategy Vision 2025 of South Africa indicated that financial inclusion is one of the South African Reserve Bank's (SARB) priority (Louis \& Chartier 2017; WBG 2017; Wentzel et al. 2016).

Financial inclusion is viewed as one of the strategies that can allow the achievement of goals of eliminating poverty unemployment and reducing inequality. The National Development Plan Vision 2030 of South Africa, acknowledges financial inclusion as one of the important tools that will contribute towards the realisation of its goals of eliminating poverty, inequality and unemployment through decent work and sustainable livelihoods (Louis \& Chartier 2017; WBG 2017). The South African government anticipates the proportion of the population who have used the banking sector or have access to transactional financial services and saving facilities to increase from about $63 \%$ to about $90 \%$ by 2030 (Louis \& Chartier 2017; WBG 2017). Financial inclusion has also been identified as a priority to continuously broaden access to banking services to poorer people and lowering costs through a combination of competitive pressures and reducing other infrastructure costs (Louis \& Chartier 2017; Mhlanga, Dunga \& Moloi 2020; WBG 2017). 
There are evidences that recognise financial inclusion as an instrument that can help to achieve financial development, economic growth, reduction in income inequality and lift households out of poverty. For instance, Keynes (1930) suggested that bank credit is the pavement along which production travels, and the bankers if they knew their duty, would provide the transport facilities to the extent required for the productive powers of the community to be employed at their full capacity. Robinson (1952) concurred with the same reasoning by arguing that financial development follows the growth and articulated causality argument by suggesting that where enterprises lead finance follows. Sarma and Pais (2008) also argued that countries can enhance efficiency and welfare by an all-inclusive financial system by providing ways to secure and safe saving practices and through promoting efficient services.

Empirically, Banerjee and Newman (1993) have observed that a critical factor that enables people to exit poverty by enhancing productivity is access to finance. Binswanger and Khandker (1995) also established that Indian bank rural expansion programme significantly lowered rural poverty and significantly increased non-agricultural employment. Also, Eastwood and Kohli (1999) in their study found that branch expansion programmes and directed lending programmes have enhanced small scale industrial output. This was supported by Bell and Rousseau (2001) who empirically established that financial intermediaries have influenced India's economic performance. Studies that try to assess and understand financial inclusion are there but limited in South Africa. Mhlanga and Denhere (2020) investigated some of the factors that may help to drive financial inclusion in South Africa using bank account ownership as a measure of financial inclusion. The study highlighted that financial inclusion in South Africa is mostly driven by age of the household, the level of education, the income, population group, gender and the marital status of the individual household. This study was supported by Mhlanga (2020) and Kaur and Kapuria (2020) who also found that education level, the monthly household consumption expenditure, the size of the land were the factors influencing financial inclusion amongst the households in rural Zimbabwe and India, respectively.

Mhlanga and Dunga (2020) also investigated the determinants of financial inclusion amongst the smallholder farmers of Zimbabwe. The study discovered that financial inclusion was driven by off-farm income, the level of education, distance to the nearest financial institution, financial literacy and the age of the household. This study also supports the results found by Kaur and Kapuria (2020) and another study by Altarawneh, Al-Nuaimi and AlNimri (2020) who examined the determinants of financial inclusion in Latin America and Europe and Brazil and Romania using the Global Findex database. The study discovered that the income level of the households and education level contribute more to financial inclusion, especially amongst the woman and young people. Motivated by the findings in these studies and the importance of financial inclusion in the growth and development agenda, the study sought to investigate the drivers of financial inclusion in South Africa using the 2018 General Household Survey data (GHS).

\section{South Africa financial system}

South Africa's banking sector currently includes 17 domestic commercial banks, two mutual banks, two cooperative banks, 14 local branches of foreign banks, as well as representative offices of 43 foreign banks (Louis \& Chartier 2017; Wentzel et al. 2016). However, there are only four (Louis \& Chartier 2017) whilst others put them at five (Louis \& Chartier 2017) major South African commercial banks who own and control more than $80 \%$ of the banking sector's total assets, approximately R4 trillion or \$285 billion (Louis \& Chartier 2017; Riley 2019; WBG 2017). The banking infrastructure in South Africa is impressive, with a network of over 5000 branches and nearly 30000 ATM's (Louis \& Chartier 2017; Nanziri \& Leibbrandt 2018; Riley 2019). The volume of electronic financial transactions (EFT) including debit card, credit card and other on-line payments have increased in the country by $60 \%$ between 2005 and 2013. On the surface, these data illustrate that South Africa's financial system is considerably more inclusive than sub-Saharan Africa and more inclusive than Eastern Europe and Central Asia, as well as the world in general. Figure 1 shows individual ownership of assets for individuals aged 18 years and older by sex, 2018.

In Figure 1, more than two-thirds, that is, $64.9 \%$ of individuals aged 18 years and above owned a bank account individually in South Africa, whilst on the other hand, 1.9\% owned the account jointly with someone else. A larger percentage of males than females in this age group, that is, $67.9 \%$ versus $65.9 \%$ owned a bank account. Approximately one-third expressed as $29.7 \%$ of individuals, exclusively or jointly, owned investment accounts whilst more than one-fifth, which is $22 \%$ owned a pension account. The statistics indicate that, in South Africa, the number of households that own an investment account is low, only a third, that is, $29.7 \%$.

Also, it argued that in South Africa less than 30\% of low-income adults the poorest $25 \%$ own a formal bank account as compared with $91 \%$ of high-income adults the richest 25\% (Louis \& Chartier 2017; Wentzel et al. 2016). The problem exists, in part, because the South African banking industry is highly concentrated in the source of wealth regions and limits access to capital to primarily the wealthy (Louis \& Chartier 2017; Nanziri \& Leibbrandt 2018; Riley 2019). As a result, the low number of households that own investment accounts in South Africa motivated the desire to investigate the factors that influence financial inclusion through the use of an investment account. The following section explains the various empirical and theoretical literature of the determinants of financial inclusion. 


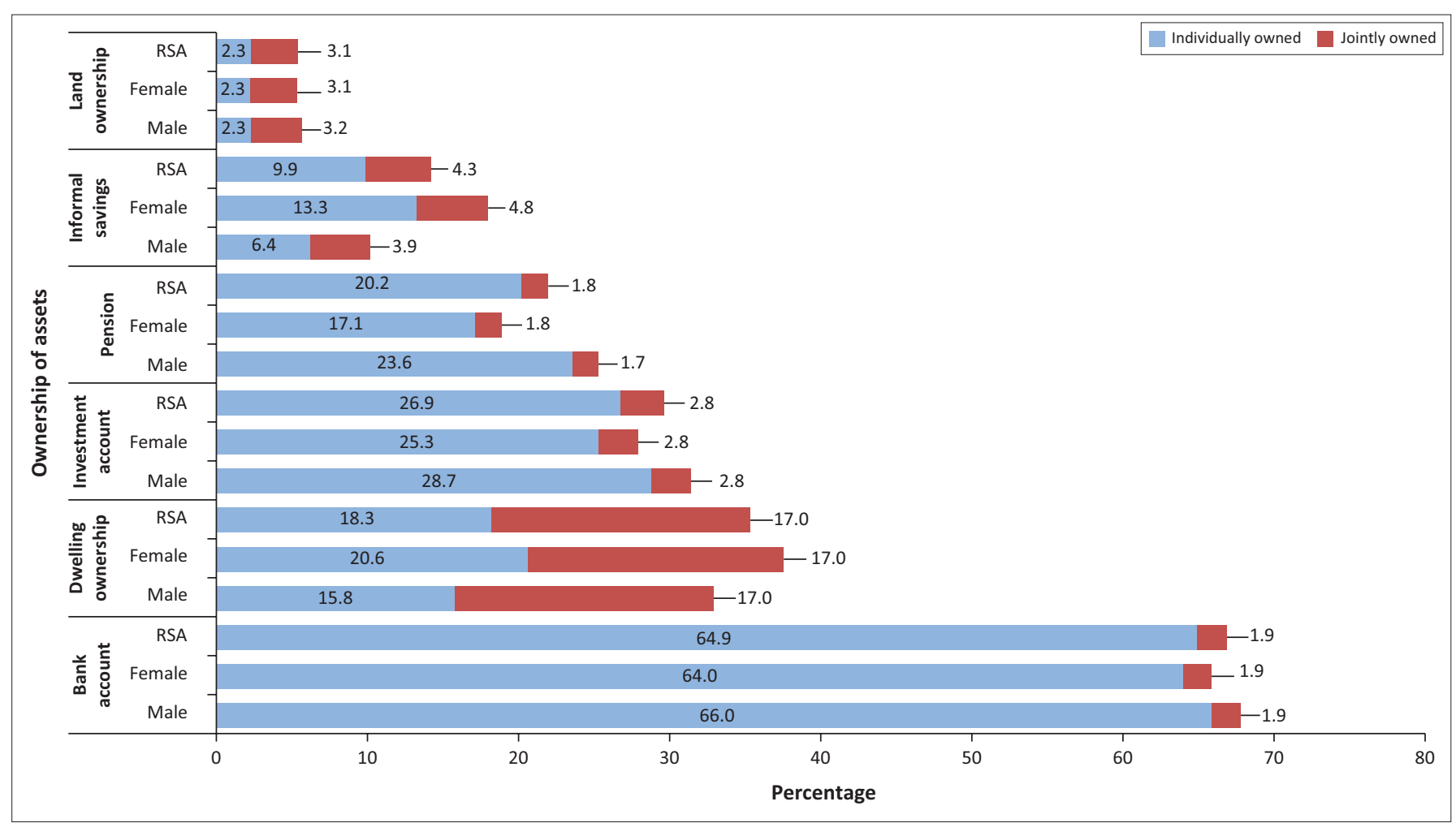

Source: Statistics South Africa (STATSSA), 2018, General household survey, Statistics South Africa, Tshwane.

RSA, Republic of South Africa.

FIGURE 1: Individual ownership of assets for individuals aged 18 years and older by sex, 2018.

\section{Literature review}

Goldsmith (1975) pioneered explicitly in the introduction of the index of financial inclusion as financial interrelation ratio. Goldsmith explained about the penetration of the financial system in terms of the number of branches, customers and capitalisation of the bank, which has gained a lot of significance in today's time. For the first time, geographers propounded the term financial exclusion in 1993, where they explain that the closing of bank branches are the reasons for limited access to bank services (Leyshon \& Thrift 1995). In recent years, the importance of an inclusive financial system has become an important policy objective in many countries. Government, banks and financial regulators both at the country level and world level have set up a new initiative for financial inclusion and new legislative regulations have been initiated in economies, hence the need to study the various theories of financial inclusion.

Oyelami, Saibu and Adekunle (2017) in the article Determinants of financial inclusion in sub-Sahara African countries, investigated the determinants of financial inclusion in sub-Saharan Africa using panel autoregressive distributed lag (ARDL). The results from the study reveal that financial inclusion in the region is meaningfully influenced by both demand-side factors, level of income and literacy and supply-side factors, interest rate and bank innovation proxy by automated teller machine (ATM) usage. By the same token, Evans (2016) in the article Determinants of financial inclusion in Africa: A dynamic panel data approach, documented the determinants of financial inclusion in Africa from the period 2005-2014, using the dynamic panel data approach. The study found out that per capita income, broad money per cent of gross domestic product (GDP), literacy rate, internet access and Islamic banking presence and activity are significant factors explaining the level of financial inclusion in Africa. Domestic credit provided by the financial sector percentage of GDP, deposit interest rates, inflation and population has insignificant impact on financial inclusion. The studies concurred on the conclusion that financial inclusion is influenced by the level of income and literacy rate in subSaharan Africa and Africa.

In addition, Yakubu et al. (2017) in the article Determining and forecasting financial inclusion in Northern Ghana using discriminant analysis, aimed to estimate a discriminant function model to analyse the determinants of financial inclusion in Northern Ghana. The study was mainly based on primary data elicited through survey questionnaires. Even though the minimum sample size was determined to be 385 households, a total of 400 households were selected systematically, out of which 395 households returned their questionnaires for analysis. The estimated function model was found to be significant at the $1 \%$ level of significance and the study found out that the most significant determinants of financial inclusion in Northern Ghana were the age of the individuals, cost of financial products, capability of the individuals, literacy level of the individuals, distance and employment status. Identically, Akudugu (2013) examined 
the determinants of financial inclusion in West Africa with a specific focus on Ghana. The study used data drawn from 1000 individuals across the various wealth classes, gender, generations, geographical locations and occupations in Ghana. The results from the logistic regression analysis highlighted that age of the individual, literacy rate, wealth class, distance from the nearest financial institution, lack of proper documentation, lack of trust for formal financial institutions, money poverty and social networks as reflected in family relations were the factors influencing financial inclusion in Ghana. These findings were supported by Mhlanga and Dunga (2020) in their study that investigated the determinants of financial inclusion in rural Zimbabwe. Mhlanga and Dunga also found that financial inclusion was driven by off-farm income, the level of education, distance to the nearest financial institution, financial literacy and the age of the household.

Uniquely, Ogunleye (2017) in the article financial inclusion and the role of women in Nigeria tested the assertion that greater lending to microfinance female clients leads to an improvement in repayment rate. The study used the unbalanced panel data framework of 752 microfinance banks in Nigeria during the period 2011-2014. The results from the regression confirm a positive impact of female inclusion on loan repayment rate. A higher proportion of female clients is associated with a greater repayment rate and with fewer loan provisions. In the same fashion, Kaur and Kapuria (2020) investigated the determinants of financial inclusion in rural India and the results indicated that financial inclusion was driven by the level of education, the monthly household consumption expenditure and the size of the land. The results were also supported by Mhlanga (2020) who carried a study on the determinants of financial inclusion in rural Zimbabwe.

\section{Methodology and data}

Relevant data for the study were extracted from the South Africa 2018 GHS data set. Individuals who did not specify whether they had an investment account and those who did not know were removed from the analysis, including those in the age group of 1-14 years who were regarded as dependent and who could not fully decide on whether to have an investment account or not. A total of 20000 individuals of the age group of 15-88 were used in the study after removing the stated groups of individuals. The data were thereafter cleaned, re-categorised and recoded as necessary. The GHS target population consisted of all private households in all nine provinces of South Africa and residents in workers' hostels.

\section{The econometric model}

The dependent variable was dichotomous, that is, either an individual has an investment account or not represented by 0 or 1 , respectively. The dependent variable was generated from the question, whether a person owns an investment account individually, jointly or not. Those who owned investment accounts jointly were regarded as owners of an investment account. As a result, the logit model was used in this study because the model has been widely used for the estimation of the choice model in most of the African countries and its advantages over other models. In Zimbabwe, for example, Sanderson, Mutandwa and Le Roux (2018) and Kiplimo et al. (2015) investigated factors influencing access to credit amongst the smallholder farmers using the logit model estimation technique in Kenya.

The other three ways that could have been used to investigate the drivers of financial inclusion, the linear probability model and the probit model were not used because of their weaknesses. The linear probability model is an extension of the linear regression model used in situations where we have qualitative dependent variables. However, the research did not use the linear probability model because of weaknesses associated with the model. The linear probability model produces dubious probability, it can be less than zero or greater than one, which is unrealistic because probability should lie between zero and one. The error term normally suffers from the problem of heteroscedasticity and they are non-normal. Marginal effects will always be constant regardless of the value of $\mathrm{Xi}$ of the dummy variable (Cameron \& Trivedi 1986; Gujarati 2009). This is mainly because it assumes a linear relationship between the dependent variable and the independent variable (Cameron \& Trivedi 1986). Because of the given weaknesses, the linear probability model was not used.

As a result, the two options available were using the logit model or the probit model. However, the researcher used the logit model because of its advantages over the probit model. One of the advantages of the logit model is that it is relatively simple to calculate for the first-order conditions and is an asymptotic distribution (Rao 1973). Also, Maddala, Li and Srivastava (2001) stated that the model is simple to compute and interpret as compared with the probit model. As we are dealing with the survey data, the logit model is appropriate than the probit model, which is appropriate for the experimental data.

\section{The logit model}

The logit model is a method of estimation used in this study. The logit model takes the following form:

$P=E\left(Y=1 / X_{i}\right)=1 /\left(1+\varepsilon\left(-\beta+\beta 2 x y_{i}\right)\right)$

which can be further expressed as follows:

$P=\frac{1}{1+e^{-z}}=\frac{e^{z}}{1+e^{z}}$

where $z$ is expressed as:

$Z_{i}=f\left(\beta_{i}+\beta_{2} X_{i}\right)$ 


\section{Specification of the model}

The model specification used in the study can be specified as follows:

Financial inclusion $=F$ (race, age, highest education level, gender, marital status, total salary). This can further be written where $P$ (Financial Inclusion $1 / X$ ) is the probability that an individual has a bank account, given the vector of the observable characteristics. The logistic function is given as $G(z)$ as shown in Equations (2) and (3):

$$
G(z)=\frac{e^{2}}{1+e^{2}}=P(\text { Financial Inclusion }=1 / x) \text {. }
$$

[Eqn 4]

\section{Definition and justification of the variable}

Dependent variable: Financial inclusion $(F I)$ explained as investment account ownership. The dependent variable is a dichotomous dependent variable, which takes value 1 when the individual had an investment account and 0 otherwise. The independent variables included in the model include gender, age, race, marital status, total salary (a proxy of income) and the highest education level. These variables are described in Table 1.

\section{Presentation and interpretation of results \\ Study population}

All the population groups in South Africa were part of the study targeted, namely black, coloured, Indian and white people. Table 2 shows the distribution of the population.

Table 1 shows that 17361 (80.9\%) of that sample were black people whilst the remaining $19.1 \%$ was shared amongst the white people (9.5\%), coloured $(7.1 \%)$ and Indian people $(2.4 \%)$. Table 2 indicates the gender distribution of the population.

\section{Gender distribution}

The results in Table 2 show that 11948 (58.4\%) are maleheaded households, whilst 8960 (41.6\%) are female-headed households. Thus, the sample size of the study had more male-headed households compared with female-headed households. The results from the estimation of the demand for an investment account using the logit model are presented in Table 4.

The results from the estimation of the drivers of financial inclusion in terms of access to an investment account in South Africa from the 2018 GHS data using the logit model are presented in Table 2. The model is free from multicollinearity as all the independent variables had a Pearson product-moment correlation coefficient, with a value of less than 0.8 in absolute terms. Kennedy (2003) outlined that, for non-continuous variables, a value of 0.8 and above in absolute terms in one of the correlation coefficients indicates a high correlation between two independent variables. Concerning the overall results of the model, the results showed that there is a positive
TABLE 1: Description of independent variables.

\begin{tabular}{|c|c|}
\hline Variable & Description \\
\hline Gender & $\begin{array}{l}\text { Is a dummy variable where } 1=\text { male and } 0 \text { otherwise? The } \\
\text { variable is expected to be }+ \text {. }\end{array}$ \\
\hline Age & $\begin{array}{l}\text { Is a continuous variable which explains the number of } \\
\text { years the individual has? The variable is expected to be }+ \text {. }\end{array}$ \\
\hline Race & $\begin{array}{l}\text { Is a categorical variable that explains the grouping of } \\
\text { humans based on shared physical or social qualities? In } \\
\text { this variable } 1=\text { black, } 2=\text { coloured, } 3=\text { Indian or Asian, } \\
4=\text { white. The variable is expected to be }-/+ \text { depending } \\
\text { on the reference category in the dummy variable. }\end{array}$ \\
\hline Marital status & $\begin{array}{l}\text { Explains whether the individual is married or not, where } \\
1=\text { legally married and } 0 \text { otherwise. The variable is } \\
\text { expected to be }+.\end{array}$ \\
\hline Total salary & $\begin{array}{l}\text { Is the total amount of income received by the individual, } \\
\text { which act as a proxy of income? The variable is expected } \\
\text { to have a positive }(+) \text { influence on financial inclusion. }\end{array}$ \\
\hline Highest education level & $\begin{array}{l}\text { Refers to the level of education of the individuals } \\
\text { expected to have a positive }(+) \text { influence on financial } \\
\text { inclusion. }\end{array}$ \\
\hline
\end{tabular}

TABLE 2: Study of population distribution.

\begin{tabular}{lcc}
\hline Race & Count out of 20 908 & Percentage \\
\hline Black & 17361 & 80.9 \\
Coloured & 1659 & 7.1 \\
Indian & 391 & 2.4 \\
White & 1497 & 9.5 \\
\hline
\end{tabular}

relationship between age, marital status, total salary (a proxy of income), highest education level, being white and being Indian on financial inclusion. On the other hand, being Coloured was associated with a negative influence on the probability of demand for an investment account. Gender with males as a reference category was the variable not significant in influencing financial inclusion.

The results show a positive and significant relationship between race, where the racial group of white people and Indian people had a positive relationship with financial inclusion where black was a reference category. Besides, the coefficient race was significant at all levels with a $p$-value of 0.000 for all the races with black as the reference category. Amongst the four races in South Africa, white people had a higher probability of demand for financial products compared with black, coloured and Indian or Asian people. The odds of demand for an investment account by white people was 3.715 higher for white people compared with black people, Indian or Asian and coloured people. Also, Indian or Asian people followed the white people, they had a higher probability of demand for an investment account compared with coloured and black people. The odds of demand for financial products for Indian people was 2.894 higher compared with coloured people who had an odds ratio of 0.695 and 0.085 for black as the reference category. Also, being a coloured person was associated with a negative influence on the demand for an investment account. However, black people had the least odds of demand for an investment account. The results indicated that being a coloured person reduces the probability of an individual to have an investment account.

The study also revealed that marital status had a positive significant impact on financial inclusion. The variable was 
TABLE 3: Gender distribution of the study.

\begin{tabular}{lcc}
\hline Gender & Frequency & Percentage \\
\hline Male headed households & 11948 & 58.4 \\
Female-headed households & 8960 & 41.6 \\
\hline Total & $\mathbf{2 0 9 0 8}$ & $\mathbf{1 0 0}$ \\
\hline
\end{tabular}

TABLE 4: Determinants of demand for an investment account-logit estimate.

\begin{tabular}{lcccccc}
\hline Variables & B & SE & Wald & df & Sig. & Exp(B) \\
\hline Step 1a & & & & & & \\
Race & - & - & 626.376 & 3 & 0.000 & - \\
Race(1) & -0.364 & 0.048 & 58.749 & 1 & 0.000 & 0.695 \\
Race(2) & 1.063 & 0.299 & 12.614 & 1 & 0.000 & 2.894 \\
Race(3) & 1.312 & 0.062 & 449.258 & 1 & 0.000 & 3.715 \\
Marital status(1) & 0.650 & 0.046 & 199.181 & 1 & 0.000 & 1.916 \\
Highest & 0.007 & 0.001 & 73.165 & 1 & 0.000 & 0.993 \\
education level & & & & & & \\
Gender(1) & 0.017 & 0.040 & 0.191 & 1 & 0.662 & 1.018 \\
Age & 0.022 & 0.001 & 455.793 & 1 & 0.000 & 1.022 \\
Total salary & 0.000 & 0.000 & 463.091 & 1 & 0.000 & 1.000 \\
Constant & -2.463 & 0.051 & 2349.945 & 1 & 0.000 & 0.085 \\
\hline
\end{tabular}

Note: Omnibus tests of model coefficients, Chi-square step 3226.393 Block 3226.393, Model 3226.393.

$B$, unstandardised beta; SE, standard error; Wald, Wald test; df, degrees of freedom Sig., statistical significance; $\operatorname{Exp}(B)$, exponentiation of the B coefficient.

Model Summary: -2 Log-likelihood 16 469.493a, Cox \& Snell $R$ Square 0.149, Nagelkerke $R$ Square 0.238.Variable(s) entered on step 1: Race, Marital status, Highest education level, Gender, Age, Total salary.

significant at all level with a $p$-value of 0.000 . The odds of demand for an investment account was 1.916 higher for married individuals compared with those who were not married. Married people had a higher likelihood of demand for financial products and services such as the investment account compared with individuals who were not married. The study also revealed that education had a positive significant influence on financial inclusion. Education was significant at $1 \%$ level of significance ( $p$-value, 0.000 ). The odds ratio for education was 0.993 . A unit change in the variable education is associated with a 0.993 change in the probability of demand for an investment account. The results were supported by Sanderson et al. (2018) who stated that educated people can quickly comprehend the various financial products on the market. This increases their likelihood of participating in the formal financial market. This was also supported by Berthoud and Kempson (1992), Kempson $(1995,2000)$. These studies agreed to the fact that educated people easily comprehend the various financial products, which increases the chances of them participating in the financial market. Louis and Chartier (2017) discovered that residence, age, education level and $94 \%$ of adults with a college degree own a bank account as compared with only $43 \%$ of those with only primary education in South Africa.

The study also revealed that the age of the individual had a positive significant relationship with the probability of demand for an investment account. The variable age had a $p$-value of 0.000 and odds ratio of 1.022. A unit change in the age of an individual, the probability of demand for an investment account will rise by approximately 1.022 . The meaning of the results was that as people grow they tend to understand the importance of financial products and services more compared with the young, this will lead them to use more of the services. This was supported by several studies, for instance, Sanderson et al. (2018) and Masiyandima, Mlambo and Nyarota (2017). The results also indicated that total salary a proxy of total income for individuals had a positive significant impact on financial inclusion. The variable was significant at $1 \%$ level of significance ( $p$-value, 0.000 ) and odds ratio of 1.000. As people's income increases by a unit, the probability of demand for an investment account increases by 1.000 . This results in the South African context makes sense because people who are working are paid their salaries through a bank, so the probability of investing the money is high for these individuals. In fact, because of high crime risk, even those who work in the informal sector are paid through a bank. This was supported by Sanderson et al. (2018) who discovered that income influences the level of financial inclusion in Zimbabwe positively. The results also indicated that the variable gender was not significant in influencing the level of use or demand for an investment account. The $p$-value for gender was 0.662 . In this case, gender was significant at all levels. In short, the drivers of financial inclusion in South Africa in relation to an investment account were age, marital status, total salary (proxy of income), highest education level, race where white people and Indians were associated with a positive influence on financial inclusion whilst coloured people was associated with a negative influence on the probability of demand for an investment account. Gender with males as a reference category was the variable not significant in influencing financial inclusion.

\section{Summary and conclusion}

The South African government is committed to improving financial inclusion and has therefore recognised the importance of financial inclusion in the NDP vision 2030 where the government envisage the proportion of the population that is banked or has access to transactional financial services and saving facilities to increase from about $63 \%$ to about $90 \%$ by 2030 . Given the government's commitment towards financial inclusion and the encouraging statistics showing improvement in key financial inclusion indicators such as access to a bank account with, $64.9 \%$ of individuals aged 18 years and above owned a bank account individually, whilst on the other hand, $1.9 \%$ owned the account jointly with someone else. However, approximately one-third expressed as $29.7 \%$ of individuals, exclusively or jointly, owned an investment account. The number of individuals who own an investment account was low, as a result, the study sought to establish the drivers of financial inclusion in South Africa concerning an investment account ownership. In line with the objective, the study established that financial inclusion is driven by age, education, the total salary proxy of income, race and marital status.

From the results, we conclude that age, education, the total salary proxy of income, race and marital status were positively related to financial inclusion. This implies that 
an increase in any of these variables significantly increases the probability of demand for financial products and services hence the level of financial inclusion in South Africa. The racial groups of white people and Indians were associated with a positive influence on the probability of demand for an investment account whilst the racial group of coloured people was associated with a negative influence on the probability of demand for an investment account. Therefore, the differences in the probability of demand amongst the different races in South Africa shows us that there is need for massive financial education amongst the other races with lower probability of demand for financial products. The negative association between being coloured people and the probability of access or demand for an investment account shows that massive financial education is required amongst the coloured people and coming up with products and services tailor-made for these racial group so that, they can also invest. It was argued that financial inclusion through access to a bank account or investment account, can help to lift people from poverty through consumption smoothening and being cushioned from economic shocks and even natural disasters.

Also, the fact that education level proved to be a significant factor in influencing financial inclusion, it is important for the government to ensure that education is intensified of the people in South Africa so that they will find it good to participate in the financial sector. Again, the study revealed that marital status had a positive significant impact on financial inclusion. The variable was significant at all levels of significance where married people had a higher likelihood of demand for financial products and services such as the investment account compared with individuals who were not married. It is important, that massive financial education is imparted amongst the households of widows, divorced and the single of the need and importance of financial inclusion through saving in fighting poverty. This will allow the government to achieve the vision 2030 articulated through the National Development Plan published in November 2011, aimed at eliminating poverty, reducing inequality and achieve full employment, decent work and sustainable livelihood.

\section{Acknowledgements}

The authors would like to express their appreciation for the University of Johannesburg and North-West University for administrative support.

\section{Competing interests}

The authors declare that they have no financial or personal relationships that may have inappropriately influenced them in writing this article.

\section{Authors' contributions}

All authors contributed to the design and implementation of the research, to the analysis of the results and to the writing of the manuscript.

\section{Ethical considerations}

This article followed all ethical standards for research without direct contact with human or animal subjects.

\section{Funding information}

This research received no specific grant from any funding agency in the public, commercial or not-for-profit sectors.

\section{Data availability}

The authors confirm that the data supporting the findings of this study are available within the article.

\section{Disclaimer}

The views and opinions expressed in this article are those of the authors and do not necessarily reflect the official policy or position of any affiliated agency of the authors.

\section{References}

Akudugu, M.A., 2013, 'The determinants of financial inclusion in Western Africa: Insights from Ghana', Research Journal of Finance and Accounting 4(8), 1-9.

Altarawneh, Y., Al-Nuaimi, M. \& Al-Nimri, A., 2020, 'The determinants of financial inclusion in Latin America and Europe (Brazil and Romania case)', Systematic Reviews in Pharmacy 11(12), 192-196.

Banerjee, A.V. \& Newman, A.F., 1993, 'Occupational choice and the process of development', Journal of Political Economy 101(2), 274-298. https://doi. org/10.1086/261876

Bell, C. \& Rousseau, P.L., 2001, 'Post-independence India: A case of finance-led industrialization?', Journal of Development Economics 65(1), 153-175. https:// doi.org/10.1016/S0304-3878(01)00132-8

Berthoud, R. \& Kempson, E., 1992, Credit and debt, Policy Studies Institute, London.

Binswanger, H.P. \& Khandker, S.R., 1995, 'The impact of formal finance on the rural economy of India', The Journal of Development Studies 32(1), 234-262. https:// doi.org/10.1080/00220389508422413

Cameron, A.C. \& Trivedi, P.K., 1986, 'Econometric models based on count data. Comparisons and applications of some estimators and tests', Journal of Applied Econometrics 1(1), 29-53. https://doi.org/10.1002/jae.3950010104

Eastwood, R. \& Kohli, R., 1999, 'Directed credit and investment in small-scale industry in India: Evidence from firm-level data 1965-78', The Journal of Development Studies 35(4), 42-63. https://doi.org/10.1080/00220389908422580

Evans, O., 2016, 'Determinants of financial inclusion in Africa: A dynamic panel data approach', MPRA Paper 81326, University Library of Munich, Munich.

Goldsmith, R.W., 1975, 'The quantitative international comparison of financial structure and development', The Journal of Economic History 35(1), 216-237. https://doi.org/10.1017/S0022050700094390

Gujarati, D.N., 2009, Basic econometrics, Tata McGraw-Hill Education, New Delhi.

Kaur, S. \& Kapuria, C., 2020, 'Determinants of financial inclusion in rural India: Does gender matter?', International Journal of Social Economics 47(6), 747-767. https://doi.org/10.1108/IJSE-07-2019-0439

Kiplimo, J.C., Ngenoh, E., Koech, W. \& Bett, J.K., 2015, 'Determinants of Access to Credit Financial Services by Smallholder Farmers in Kenya', Journal of Development and Agricultural Economics 7(9), 303-313.

Kempson, E., 1994, Outside the banking system, Policy Studies Institute, London.

Kempson, E., 2000, In or out?: Financial exclusion: Literature and research review, Personal Finance Research Centre, Bristol.

Kennedy, P., 2003, A guide to econometrics, MIT Press, Cambridge, MA.

Keynes, J.M., 1930, A treatise on money: In two volumes, Macmillan Company, London.

Laha, A., Kuri, D. \& Kumar, P., 2011, 'Determinants of financial inclusion: A study of some selected districts of West Bengal, India', Indian Journal of Finance 5(1), 29-36.

Leyshon, A. \& Thrift, N., 1995, 'Geographies of financial exclusion: financial abandonment in Britain and the United States', Transactions of the Institute of British Geographers, 312-341.

Louis, L. \& Chartier, F., 2017, 'Financial inclusion in South Africa: An integrated framework for financial inclusion of vulnerable communities in South Africa's regulatory system reform', Journal of Comparative Urban Law and Policy 1(1), 13.

Maddala, G., Li, H. \& Srivastava, V., 2001, 'A comparative study of different shrinkage estimators for panel data models', Annals of Economics and Finance 2(1), 1-30. 
Masiyandima, N., Mlambo, K. \& Nyarota, S., 2017, 'Financial inclusion and quality of livelihood in Zimbabwe', in 14th African finance conference, May, 17-18, 2017, University of Zimbabwe, Africa Growth Institute, Victoria Falls.

Mhlanga, D., 2020, 'Financial inclusion and poverty reduction: Evidence from small scale agricultural sector in Manicaland Province of Zimbabwe', Doctora dissertation, North-West University, Tlokwe.

Mhlanga, D. \& Denhere, V., 2020, 'Determinants of financial inclusion in Southern Africa', Studia Universitatis Babes-Bolyai 65(3), 39-52. https://doi.org/10.2478/ subboec-2020-0014

Mhlanga, D. \& Dunga, S.H., 2020, 'Measuring financial inclusion and its determinants among the smallholder farmers in Zimbabwe: An empirical study', Eurasian Journal of Business and Management 8(3), 266-281. https://doi.org/10.15604/ ejbm.2020.08.03.008

Mhlanga, D., Dunga, S.H. \& Moloi, T., 2020, 'Financial inclusion and poverty alleviation among smallholder farmers in Zimbabwe', Eurasian Journal of Economics and Finance 8(3), 168-182. https://doi.org/10.15604/ejef.2020.08.03.004

Nanziri, E.L. \& Leibbrandt, M., 2018, 'Measuring and profiling financial literacy in South Africa', South African Journal of Economic and Management Sciences 21(1), 1-17. https://doi.org/10.4102/sajems.v21i1.1645

Ogunleye, T.S., 2017, 'Financial inclusion and the role of women in Nigeria', African Development Review 29(2), 249-258. https://doi.org/10.1111/1467-8268.12254

Oyelami, L.O., Saibu, O.M. \& Adekunle, B.S., 2017, 'Determinants of financial inclusion in sub-Sahara African countries', Covenant Journal of Business and Socia Sciences 8, 104-116.

Rao, C.R., 1973, Linear statistical inference and its applications, Wiley, New York, NY.
Riley, T.A., 1995, 'South Africa: Reducing Financial Constraints to Emerging Enterprises', World Bank Other Operational Studies 9987, The World Bank, Washington, D.C., United States of America.

Robinson, J., 1952, 'The generalization of the general theory', in R.M. Goodwin (ed.), The rate of interest and other essays, pp. 777-780, MacMillan, London.

Sanderson, A., Mutandwa, L. \& Le Roux, P., 2018, 'A review of determinants of financial inclusion', International Journal of Economics and Financial Issues $8(1), 1$.

Sarma, M. \& Pais, J., 2008, 'Financial inclusion and development: A cross country analysis', in Annual Conference of the HDCA (Human Development and Capability Association): Equality, Inclusion and Human Development, September, 10-13, New Delhi, pp. 10-13.

Statistics South Africa (STATSSA), 2018, General household survey, Statistics South Africa, Tshwane.

World Bank Group (WBG), 2017, Achieving effective financial inclusion in South Africa, The World Bank and the Government of South Africa, Tshwane.

World Bank Group, 2018, Universal Financial Access by 2020: Overview, The World Bank, Washington, DC

Wentzel, J.P., Diatha, K.S. \& Yadavalli, V.S.S., 2016, 'An investigation into factors impacting financial exclusion at the bottom of the pyramid in South Africa Development Southern Africa 33(2), 203-214. https://doi.org/10.1080/037683 5X.2015.1120648

Yakubu, I., Dinye, R., Buor, D. \& Iddrisu, W.A., 2017, 'Determining and forecasting financial inclusion in Northern Ghana using discriminant analysis', International Research Journal of Finance and Economics 163(1), 61-72. 